ISSN: 1896-4087

DOI: http://dx.doi.org/10.21784/ZC.2018.004

\title{
Opłata reklamowa jako instrument ochrony krajobrazu - uwagi de lege lata i de lege ferenda
}

\author{
Advertising fee as a tool for landscape protection - remarks \\ de lege lata and de lege ferenda
}

\begin{abstract}
Streszczenie:
W artykule podjęto próbę przedstawienia konstrukcji prawnej szczególnej daniny publicznej, wprowadzonej przez ustawodawcę ponad dwa lata temu, jaką jest opłata reklamowa. Opłata reklamowa to danina o charakterze fakultatywnym stanowiąca dochód budżetu gminy. Kwalifikowana jest ona do kategorii obciążeń publicznoprawnych nieruchomości. Publikacja ma na celu przedstawienie charakteru prawnego tej opłaty oraz wskazanie podstawowych problemów praktycznych powstających na etapie stosowania tych przepisów przez podmioty występujące w stosunkach podatkowoprawnych. Artykuł został wzbogacony o uwagi de lege ferenda, które po wprowadzeniu przez ustawodawcę zniwelują wątpliwości natury prawnej.

Artykuł powstał w oparciu o analizę aktualnych przepisów ustawy o podatkach i opłatach lokalnych dotyczących opłaty reklamowej oraz bogatej literatury przedmiotu autorstwa cenionych teoretyków prawa podatkowego.
\end{abstract}

Słowa kluczowe: reklama, tablica reklamowa, urządzenie reklamowe, opłata reklamowa, opłaty lokalne

\section{Abstract:}

The article attempts to present the legal structure of the special public tribute, introduced by the legislature more than two years ago, which is the advertising fee. The advertising fee is an optional tribute constituting the income of the commune budget. 
Sylwia Gontowska, Robert Kwaśniewski - Opłata reklamowa...

It is qualified to the category of public real estate charges. The publication was aimed at presenting the legal nature of this fee and an indication of the basic practical problems arising at the stage of the application of those rules by operators occurring in relations tax and legal. The article has been enriched with the remarks de lege ferenda, which, when introduced by the legislature, eliminates doubts of a legal nature.

The article was based on an analysis of the current provisions of the Local Taxes and Fees Act on advertising fees and rich literature of the subject of esteemed theorists of tax law.

Keywords: advertisement, billboard, advertising device, advertising fee, local fees

\section{Wprowadzenie}

Z dniem 11 września 2015 roku weszły w życie przepisy ustawy z dnia 24 kwietnia 2015 r. o zmianie niektórych ustaw w związku ze wzmocnieniem narzędzi ochrony krajobrazu${ }^{1}$, które do polskiego systemu podatkowego wprowadziły m.in. nową daninę publiczną o charakterze fakultatywnym, jaką jest opłata reklamowa. Konstrukcja prawna tej opłaty uregulowana została przez ustawodawcę w ustawie z dnia 12 stycznia 1991 r. o podatkach i opłatach lokalnych², zaś kwestię czyim dochodem są wpływy z tej opłaty określają przepisy znowelizowanej ${ }^{3}$ ustawy z dnia 13 listopada 2003 r. o dochodach jednostek samorządu terytorialnego ${ }^{4}$.

Wprowadzenie do obrotu prawnego kolejnej daniny publicznej stanowiącej dochód budżetów gmin rodzi pytanie dotyczące celu analizowanej opłaty, a mianowicie czy motywem wprowadzenia przez ustawodawcę opłaty reklamowej był głównie cel fiskalny czy też przyczynkiem do jej wprowadzenia były cele pozafiskalne nastawione na ochronę krajobrazu i przestrzeni publicznej przed naruszeniem ładu krajobrazowego spowodowanym lawiną reklam. Jak wskazuje się w doktrynie, w przypadku opłaty reklamowej cel fiskalny ma znaczenie

\footnotetext{
${ }^{1}$ Dz.U. z 2015 r., poz. 774.

${ }^{2}$ Tekst jedn.: Dz.U. z 2016 r., poz. 716 ze zm., dalej jako u.p.o.l.

${ }^{3}$ Na podstawie art. 1 ustawy z dnia 25 września 2015 r. o zmianie ustawy o dochodach jednostek samorządu terytorialnego (Dz.U. z 2015 r., poz. 1685) znowelizowano art. 4 pkt 2 ustawy stanowiący katalog dochodów własnych gmin poszerzając go o literę „ca” - opłata reklamowa.

${ }^{4}$ Tekst jedn.: Dz.U. z 2016 r., poz. 198 ze zm.
} 
wtórne ${ }^{5}$. Opłata reklamowa została wprowadzona niejako „przy okazji" implementacji rozwiązań prawnych wynikających z ratyfikowanej przez Polskę w dniu 24 czerwca 2004 roku Europejskiej Konwencji Krajobrazowej sporządzonej 20 października 2000 roku we Florencji ${ }^{6}$.

Głównym celem ustawy wprowadzającej opłatę reklamową, jak wskazuje ustawodawca $\mathrm{w}$ uzasadnieniu do projektu ustawy, jest „wdrożenie rozwiązań, które zapewnią właściwy poziom ochrony szczególnie cennym krajobrazowo obszarom Polski" ${ }^{7}$. Ponadto ustawodawca stwierdza, że „możliwość pozyskania dodatkowych dochodów powinna przysługiwać jedynie tym gminom, w których podejmowane są działania w kierunku uporządkowania przestrzeni publicznej; opłata za reklamy ma stanowić jedno z narzędzi takiego porządkowania, nie zaś źródło uzyskania łatwego dochodu"8.

W związku z powyższym opłata reklamowa nie stanowi w zamierzeniu ustawodawcy źródła dodatkowego dochodu publicznego, lecz jest jednym z instrumentów zmierzających do uporządkowania przestrzeni publicznej i ochrony krajobrazu. Funkcja fiskalna w tym przypadku nie ma większego znaczenia, gdyż pierwszorzędne znaczenie będą miały funkcje pozafiskalne. W literaturze dominuje pogląd, iż opłata reklamowa posiada istotny walor regulacyjny, który dominuje nad funkcją fiskalną ${ }^{9}$. Cel regulacyjny wyraża się w tym, że ciężar publiczny, który miałby być poniesiony w związku z opłatą reklamową spowoduje zmniejszenie liczby reklam i urządzeń reklamowych w przestrzeni publicznej, co w konsekwencji doprowadzi do zapobieżenia degradacji

${ }^{5} \mathrm{~J}$. Wantoch-Rekowski, $O$ opłacie reklamowej, [w:] W. Miemiec (red.), Księga Jubileuszowa Profesor Krystyny Sawickiej. Gromadzenie i wydatkowanie środków publicznych. Zagadnienia finansowoprawne, Wrocław 2017, s. 290-297; D. Antonów, Charakter prawny opłaty reklamowej, [w:] „Finanse Komunalne” 2017, nr 1-2, s. 106-118.

${ }^{6}$ Konwencja ta została ratyfikowana przez Prezydenta Rzeczypospolitej Polskiej w dniu 24 czerwca 2004 r., w krajowym porządku prawnym zaczęła obowiązywać od 1 stycznia 2005 roku.

${ }^{7}$ Druk sejmowy nr 1525 z dnia 28 czerwca 2013 r., s. 26 uzasadnienia.

${ }^{8}$ Ibidem, s. 18 uzasadnienia.

${ }^{9}$ Zob. D. Antonów, Charakter prawny..., op. cit., s. 106-118; A. Fogel, G. Goleń (red.), Komentarz do ustawy z dnia 24 kwietnia 2015r. o zmianie niektórych ustaw w zwiqzzu ze wzmocnieniem narzędzi ochrony krajobrazu (stan prawny: 1 grudnia 2015r.), LEX el. 
Sylwia Gontowska, Robert Kwaśniewski - Opłata reklamowa...

ładu krajobrazowego ${ }^{10}$. W doktrynie słusznie zwraca się uwagę na pewien paradoks związany z określeniem głównego celu tej opłaty. A mianowicie jeżeli głównym celem opłaty reklamowej jest wyeliminowanie reklam i urządzeń reklamowych z polskiego krajobrazu, to jednocześnie realizacja tego celu wyeliminuje przedmiot tej opłaty, co w konsekwencji spowoduje brak wpływów do budżetu gminy z jej tytułu $^{11}$. 0 ograniczonym wpływie tej opłaty na dochody gmin przesądza nie tylko jej konstrukcja, nieobligatoryjność czy skomplikowany tryb ustanawiania i poboru, ale również i to, że została pomyślana jako narzędzie służące ochronie krajobrazu ${ }^{12}$.

\section{Konstrukcja prawna opłaty reklamowej}

Konstrukcja prawna opłaty reklamowej została uregulowana przez ustawodawcę w art. 17a oraz 17b u.p.o.l. Elementami konstrukcyjnymi opłaty, które będą analizowane poniżej są: przedmiot opłaty, podmiot zobowiązany do uiszczania opłaty, stawki opłaty, zasady jej poboru, a także zwolnienia i wyłączenia od obowiązku uiszczania opłaty reklamowej.

Zgodnie z art. 17a ust. 1 ustawy „rada gminy może wprowadzić opłatę reklamową od umieszczonych tablic reklamowych oraz urządzeń reklamowych". Takie sformułowanie przepisu oznacza, iż ustawodawca, podobnie jak w stosunku do pozostałych opłat lokalnych, przyjął koncepcję ich fakultatywnego wprowadzania przez radę gminy. Rada gminy może, ale nie musi w drodze uchwały wprowadzić na swoim terytorium opłaty reklamowej. Przedmiotem tej opłaty są rozmieszczone na terenie danej gminy tablice reklamowe bądź urządzenia reklamowe. Pojęcia „tablica reklamowa” oraz „urządzenie reklamowe” zostały zdefiniowane w art. 1a ust. 1 u.p.o.l, który jest słowniczkiem pojęć ustawowych. W punkcie 3a tego przepisu ustawodawca wskazuje, że użyte w ustawie określenia - reklama, tablica reklamowa,

\footnotetext{
${ }^{10}$ D. Antonów, Charakter prawny..., op. cit., s. 107-108.

${ }^{11}$ S. Czarnecki, Opłata reklamowa - wątpliwe źródło dochodów gmin?, „Przegląd Podatków Lokalnych i Finansów Samorządowych" 2016, nr 3, s. 16.

${ }^{12}$ Ibidem.
} 
urządzenie reklamowe, szyld - oznaczają odpowiednio reklamę, tablicę reklamową, urządzenie reklamowe, szyld w rozumieniu przepisów ustawy z dnia 27 marca 2003 roku o planowaniu i zagospodarowaniu przestrzennym ${ }^{13}$. Taki zabieg ustawodawcy polegający na odesłaniu do przepisów innej ustawy z punktu widzenia techniki prawodawczej należy ocenić pozytywnie, gdyż nie powielamy dwóch identycznych definicji legalnych, a korzystamy z wcześniejszego dorobku legislacyjnego.

Możliwość wprowadzenia opłaty reklamowej została przez ustawodawcę ograniczona przez obowiązek podjęcia przez radę gminy uchwały dotyczącej zasad i warunków sytuowania obiektów małej architektury, tablic reklamowych i urządzeń reklamowych oraz ogrodzeń. Obowiązek taki wynika bezpośrednio z art. 17a ust. 2 u.p.o.l. Pobieranie opłaty reklamowej na obszarach, na których taka „uchwała reklamowa"14 nie obowiązuje nie będzie zatem możliwe. Procedurę wprowadzenia uchwały w sprawie zasad i warunków sytuowania obiektów małej architektury, tablic reklamowych i urządzeń reklamowych oraz ogrodzeń, ich gabaryty, standardy jakościowe oraz rodzaje materiałów budowlanych z jakich mogą być wykonane określa art. 37a u.p.z.p. Postępowanie zmierzające do ustalenia przez organ stanowiący gminy powyższych zasad i warunków jest dwuetapowe. Pierwszym krokiem jest podjęcie przez radę gminy, zgodnie $\mathrm{z}$ art. 37b ust. 1 u.p.z.p., uchwały o przygotowaniu przez wójta (burmistrza, prezydenta miasta) projektu wyżej wspominanej uchwały. Etap ten wszczyna całą procedurę związaną z podjęciem „uchwały reklamowej”. Po uchwaleniu takiego aktu przez radę gminy wójt zobowiązany jest do niezwłocznego podjęcia czynności w oparciu o dyspozycję zawartą w art. 37b ust. 2 u.p.z.p. ${ }^{15}$

${ }^{13}$ Tekst jedn.: Dz.U. z 2016 r., poz. 778 ze zm., dalej jako u.p.z.p.

${ }^{14} \mathrm{~W}$ literaturze przedmiotu uchwała w sprawie zasad i warunków sytuowania obiektów małej architektury, tablic reklamowych i urządzeń reklamowych oraz ogrodzeń nazywana jest uchwałą reklamową. Zob. T. Brzezicki, Kara za niezgodne z prawem umieszczenie reklam, „Przegląd Podatkowy” 2016, nr 8, s. 35-40; T. Brzezicki, Komentarz do art. 17a ustawy o podatkach i opłatach lokalnych, [w:] W. Morawski (red.), Ustawa o podatkach i opłatach lokalnych. Komentarz, Gdańsk 2016, s. 482 i n.

${ }^{15}$ Obowiązki wójta wynikające z przepisów ustawy o planowaniu i zagospodarowaniu przestrzennym związane z przygotowaniem projektu uchwały reklamowej szczegółowo omawia K. Stelmaszczyk, Komentarz do art. 17a ustawy o podatkach i opłatach 
Sylwia Gontowska, Robert Kwaśniewski - Opłata reklamowa...

Po dokonaniu stosownych uzgodnień i uzyskaniu wymaganych prawem opinii innych organów, rada gminy w formie uchwały, stanowiącej akt prawa miejscowego (art. 37a ust. 4 u.p.z.p.), ustala zasady i warunki sytuowania obiektów małej architektury, tablic reklamowych i urządzeń reklamowych oraz ogrodzeń, ich gabaryty, standardy jakościowe oraz rodzaje materiałów budowlanych z jakich mogą być wykonane. Jeżeli „uchwała reklamowa” wejdzie w życie ${ }^{16}$, rada gminy może uchwalić uchwałę wprowadzającą opłatę reklamową jedynie na obszarach gminy, na których obowiązują warunki i zasady wynikające z uchwały reklamowej.

Podmioty zobowiązane do uiszczania opłaty reklamowej określa art. 17a ust. 3 u.p.o.l. Zgodnie z tym przepisem opłatę reklamową pobiera się od:

1) właścicieli nieruchomości lub obiektów budowlanych, z wyłączeniem nieruchomości gruntowych oddanych w użytkowanie wieczyste,

2) użytkowników wieczystych nieruchomości gruntowych,

3) posiadaczy samoistnych nieruchomości lub obiektów budowlanych,

4) posiadaczy nieruchomości lub ich części albo obiektów budowlanych lub ich części, stanowiących własność Skarbu Państwa lub jednostki samorządu terytorialnego, jeżeli posiadanie:

a) wynika z umowy zawartej z właścicielem, Agencją Nieruchomości Rolnych lub z innego tytułu prawnego,

b) jest bez tytułu prawnego

- jeżeli na tych nieruchomościach lub obiektach budowlanych znajdują się tablice reklamowe lub urządzenia reklamowe, niezależnie od tego czy na tablicy reklamowej lub urządzeniu reklamowym eksponowana jest reklama.

lokalnych, [w:] P. Borszowski, K. Stelmaszczyk, Podatki i opłaty lokalne, podatek rolny, podatek leśny. Komentarz, Warszawa 2016, s. 329-330.

16 „Uchwała reklamowa”, będąca aktem prawa miejscowego, obligatoryjnie musi zostać opublikowana w Wojewódzkim Dzienniku Urzędowym, co jest niezbędne dla wejścia w życie takiej uchwały. 
Regulacja zawarta w powyższym przepisie jest zbieżna z katalogiem podmiotów, na których ciąży obowiązek podatkowy w podatku od nieruchomości, wynikającym z art. 3 ust. 1 u.p.o.l. W dużym uproszczeniu można stwierdzić, iż podatnik podatku od nieruchomości ponosi opłatę reklamową niezależnie od tego, czy faktycznie wykorzystuje obiekt reklamowy zgodnie z jego przeznaczeniem ( $\mathrm{tj}$. czy na tablicy lub urządzeniu reklamowym eksponowana jest reklama). Należy zauważyć, że podmiotem zobowiązanym do uiszczania opłaty reklamowej nie jest właściciel tablicy reklamowej lub urządzenia reklamowego, który faktycznie eksponuje reklamę, a podmiot na którego nieruchomości lub obiekcie budowlanym znajdują się te urządzenia.

W art. 17a ust. 4 ustawodawca w przypadku współwłasności lub współposiadania nieruchomości lub obiektu budowlanego, na których zlokalizowana jest tablica reklamowa lub urządzenie reklamowe przewidział istnienie solidarnej odpowiedzialności za wniesienie opłaty reklamowej. Na gruncie prawa publicznego takie zobowiązanie jest niepodzielne, co w praktyce oznacza, że nie ma znaczenia, który ze współwłaścicieli lub współposiadaczy faktycznie użytkuje tablicę reklamową lub urządzenie reklamowe i kto czerpie z tego korzyści. W takim przypadku o powstaniu obowiązku zapłaty decydować będzie jedynie współwłasność lub fakt współposiadania nieruchomości lub obiektu budowlanego ${ }^{17}$.

Przechodząc do katalogu zwolnień przedmiotowych, to ustawodawca dokonał ich wyliczenia w art. 17a ust. 5 wskazując, że opłaty reklamowej nie pobiera się, jeżeli tablice reklamowe lub urządzenia reklamowe, o których mowa w ust. 2:

1) nie są widoczne z przestrzeni dostępnych publicznie,

2) stanowią szyld, o ile jest on zgodny z zasadami i warunkami sytuowania obiektów małej architektury, tablic reklamowych i urządzeń reklamowych oraz ogrodzeń,

${ }^{17}$ Zob. M. Hadel, Opłata reklamowa jako instrument kształtowania gminnej polityki przestrzennej, „Finanse Komunalne” 2016, nr 7-8, s. 89; A. Fogel, G. Goleń, A. Staniewska (red.), Ustawa krajobrazowa. Komentarz do przepisów wprowadzonych w zwiq̨zu ze wzmocnieniem narzędzi ochrony krajobrazu, Warszawa 2016, s. 71. 
Sylwia Gontowska, Robert Kwaśniewski - Opłata reklamowa...

3) są realizacją obowiązku nałożonego przepisami prawa,

4) służą wyłącznie do upowszechniania informacji:

a) trwale upamiętniającej osoby, instytucje lub wydarzenia,

b) o charakterze religijnym, związanym z działalnością kościołów lub innych związków wyznaniowych, jeżeli tablica reklamowa lub urządzenie reklamowe sytuowane są w granicach terenów użytkowanych jako miejsca kultu i działalności religijnej oraz cmentarzy.

Poniżej podjęte zostaną rozważania dotyczące wybranych zwolnień przedmiotowych wprowadzonych przez ustawodawcę w zakresie opłaty reklamowej. W jednym w przepisów ustawodawca stanowi, że nie pobiera się opłaty reklamowej, jeżeli tablice lub urządzenia reklamowe nie są widoczne z przestrzeni dostępnych publicznie. Zwolnienie to w praktyce może wywoływać szereg wątpliwości związanych po pierwsze z pojęciem „przestrzeni publicznej” (brak definicji legalnej w przepisach prawa podatkowego oraz normach regulujących planowanie i zagospodarowanie przestrzenne), a po drugie z kwestią widoczności z tej przestrzeni. Mimo tego, że ustawodawca w przepisach ustawy o planowaniu i zagospodarowaniu przestrzennym posługuje się pojęciem „obszaru przestrzeni publicznej”, to nie należy go utożsamiać z pojęciem „przestrzeni publicznej” użytej w przepisach ustawy o podatkach i opłatach lokalnych, gdyż nie zdecydował się on na odesłanie do przepisów innej ustawy w związku z tym pojęciem ${ }^{18}$. Doktryna wskazuje, że w przypadku braku definicji legalnej „,przestrzeni publicznej" należałoby przyjąć, iż jest to przestrzeń dostępna dla nieokreślonych imiennie osób, np. drogi i place publiczne, przestrzenie budynków użyteczności publicznych (szkoły, uczelnie, urzędy) oraz dostępne przestrzenie galerii handlowych ${ }^{19}$. Jeżeli chodzi o kwestię widoczności z przestrzeni publicznej to należy uznać, że urządzenie reklamowe lub tablica reklamowa jest widoczna z danego miejsca pod warunkiem, że osoba o przeciętnym wzroku bez używania urządzeń poprawiających

\footnotetext{
${ }^{18}$ Szerzej na ten temat: M. Hadel, Opłata reklamowa ..., op. cit., s. 91-92.

${ }^{19}$ T. Brzezicki, Komentarz do art.17a ustawyo podatkachiopłatachlokalnych..., op. cit., s. $484-485$.
} 
widoczność jest w stanie odczytać treść na niej umieszczonej o charakterze reklamowym ${ }^{20}$.

Ustawodawca wskazuje, że zwolnieniu podlegają tablice reklamowe lub urządzenia reklamowe w przypadku, gdy ich usytuowanie jest związane z realizacją obowiązku nałożonego przepisami prawa. Dla zastosowania tego zwolnienia istotnym będzie istnienie regulacji szczególnej, która zobowiązuje dany podmiot do zamieszczenia informacji stanowiącej w pewien sposób reklamę. Tytułem przykładu można wskazać art. 18 ust. 1 ustawy z dnia 29 sierpnia 1997 r. o komornikach sądowych i egzekucji ${ }^{21}$, w którym to komornik zobowiązany jest, po uzgodnieniu z prezesem sądu rejonowego, wywiesić na tablicy informacyjnej dni i godziny przyjęć interesantów. Taka tablica mogłaby zostać uznana za obiekt reklamowy, ale w związku z wyłączeniem wprowadzonym przez ustawodawcę nie będzie podlegać opłacie reklamowej ${ }^{22}$.

Kolejnym elementem konstrukcji prawnej opłaty reklamowej jest kwestia jej wysokości. Ustawodawca w art. 17b określił składniki opłaty reklamowej. Składa się ona z dwóch części - stałej i zmiennej. Część stała ma zryczałtowaną wysokość niezależną od pola powierzchni tablicy reklamowej lub urządzenia reklamowego służącego ekspozycji reklamy. Część zmienna zaś zależy od wielkości pola powierzchni tablicy lub urządzenia reklamowego służących ekspozycji reklamy. W przypadku, kiedy kształt reklamy uniemożliwia wyznaczenie pola tej ekspozycji, to wysokość opłaty zależy od pola powierzchni bocznej prostopadłościanu opisanego na urządzeniu reklamowym.

Warto zaznaczyć, że w art. 17a ust. 6 poruszono także ważną kwestię zaliczenia na poczet opłaty reklamowej należnej od tablicy reklamowej lub urządzenia reklamowego kwoty zapłaconego podatku od nieruchomości od tej tablicy bądź urządzenia reklamowego. Związane jest to z uznaniem tablic i urządzeń reklamowych za budowle. Bez przewidzianej kompensacji podatnik odrębnie ponosiłby obowiązek zapłaty podatku od nieruchomości i opłaty reklamowej. Należy

\footnotetext{
${ }^{20}$ M. Hadel, Opłata reklamowa..., op. cit., s. 92.

${ }^{21}$ Tekst jedn.: Dz.U. z 2017 r., poz. 1277.

${ }^{22}$ T. Brzezicki, Komentarz do art. 17a..., op. cit., s. 485.
} 
Sylwia Gontowska, Robert Kwaśniewski - Opłata reklamowa...

podkreślić jednak, że nie każda tablica lub urządzenie reklamowe jest opodatkowane. Pomimo takiego rozwiązania organ podatkowy nie jest zwolniony z prowadzenia odrębnej ewidencji dla potrzeb podatku od nieruchomości i odrębnej dla potrzeb opłaty reklamowej ${ }^{23}$. Regulacja przepisu art. 17a ust. 6 pozwala na uniknięcie podwójnego opodatkowania „budowli” będących jednocześnie tablicami reklamowymi lub urządzeniami reklamowymi ${ }^{24}$. W praktyce może to rodzić problemy związane z tym, że znaczna część podatników podatku od nieruchomości wskazuje w składanych przez nich deklaracjach, zbiorcze dane odnośnie wartości budowli do opodatkowania ogółem ${ }^{25}$.

Maksymalne stawki opłaty reklamowej określa art. 19 pkt 1 lit. g) i h) u.p.o.l. W 2018 roku stawka części stałej opłaty reklamowej nie może przekroczyć - 2,50 zł dziennie, zaś stawka części zmiennej opłaty reklamowej nie może przekroczyć - 0,21 zł dziennie od $1 \mathrm{~m}^{2}$ pola powierzchni tablicy reklamowej lub urządzenia reklamowego służących ekspozycji reklamy ${ }^{26}$.

Rada gminy określa wysokość stawek opłaty reklamowej podejmując stosowną uchwałę z tym, że nie może ona przekroczyć stawek maksymalnych wskazanych w ustawie. Posiada jednak uprawnienie do różnicowania wysokości stawek opłaty reklamowej, uwzględniając lokalizację oraz wielkość lub rodzaj tablicy reklamowej lub urządzenia reklamowego, co wynika z art. 19 pkt 4 u.p.o.l. Różnicowanie może dotyczyć części stałej, jak i części zmiennej opłaty.

\section{Charakter prawny opłaty reklamowej}

Z uwagi na umiejscowienie opłaty reklamowej w przepisach ustawy o podatkach i opłatach lokalnych, a dochodów z tytułu jej pobierania

\footnotetext{
${ }^{23}$ Ibidem, s. 486.

${ }^{24}$ B. Pahl, Podatki i opłaty lokalne. Teoria i praktyka, Warszawa 2017, s. 296.

${ }^{25} \mathrm{M}$. Łyczek, Opłata reklamowa - nowa opłata lokalna jako instrument ochrony krajobrazu, „Przegląd Podatków Lokalnych i Finansów Samorządowych” 2015, nr 6, s. 22.

${ }^{26}$ Obowiązująca stawka opłaty reklamowej wynika z obwieszczenia Ministra Finansów z dnia 28 lipca 2017 r. w sprawie górnych granic stawek kwotowych podatków i opłat lokalnych w 2017 r. (M.P. z 2017 r., poz. 800).
} 
w art. 4 pkt 2 ustawy o dochodach jednostek samorządu terytorialnego, a więc wśród opłat będących dochodami własnymi gmin, opłatę reklamową można zakwalifikować jako opłatę będącą daniną publiczną ${ }^{27}$. Zaliczenie opłaty reklamowej do danin publicznych będących opłatami wzbudza jednakże pewne wątpliwości natury prawnej. Sama nazwa nie jest wystarczającą przesłanką do uznania analizowanego świadczenia za opłatę, więc w pierwszej kolejności należałoby zbadać charakter prawny opłaty reklamowej, skupiając się na cechach konstytutywnych tego świadczenia.

W literaturze trafnie podkreśla się, że opłata jest daniną publiczną, która charakteryzuje się tymi samymi cechami, co podatek (publicznoprawność, przymusowość, bezzwrotność, jednostronność ustalania, charakter pieniężny), z tym że w przeciwieństwie do podatku, opłata posiada cechę odpłatności. Odpłatność, najprościej rzecz ujmując, polega na tym, iż w zamian za świadczenie pieniężne wnoszący je podmiot otrzymuje od związku publicznoprawnego, na rzecz którego opłata jest wnoszona, świadczenie wzajemne (głównie w formie usługi), którego wartość zazwyczaj odpowiada wartości świadczenia pieniężnego. W doktrynie taka sytuacja nazywa się pełną ekwiwalentnością świadczenia ${ }^{28}$.

W przypadku opłaty reklamowej trudnością jest wskazanie świadczenia wzajemnego jakie realizuje samorząd gminny w zamian za pobieranie tej opłaty. Opłacie reklamowej, jak wskazuje się w doktrynie, nie odpowiada żadne świadczenie wzajemne, nie jest ona zapłatą za korzystanie z publicznej infrastruktury i nie jest rekompensatą za uszczerbek

${ }^{27}$ Zgodnie z art. 5 ust. 2 pkt 1 ustawy z dnia 27 sierpnia 2009 r. o finansach publicznych (tekst jedn.: Dz.U. z 2017 r., poz. 2077 ze zm.) do danin publicznych zalicza się: „podatki, składki, opłaty, wpłaty z zysku przedsiębiorstw państwowych i jednoosobowych spółek Skarbu Państwa oraz banków państwowych, a także inne świadczenia pieniężne, których obowiązek ponoszenia na rzecz państwa, jednostek samorządu terytorialnego, państwowych funduszy celowych oraz innych jednostek sektora finansów publicznych wynika z odrębnych ustaw".

${ }^{28}$ Zob. B. Brzeziński, A. Olesińska (red.), Prawo finansów publicznych, Toruń 2017, s. 234; B. Brzeziński, Wprowadzenie do prawa podatkowego, Toruń 2008, s. 38; Z. Ofiarski, Ogólne prawo podatkowe. Zagadnienia materialnoprawne i proceduralne, Warszawa 2013 , s. 25. 
Sylwia Gontowska, Robert Kwaśniewski - Opłata reklamowa...

w środowisku naturalnym ${ }^{29}$. Brak wyraźnie określonej czynności wzajemnej ze strony gminy, która to świadczenie pieniężne pobiera, upodabnia opłatę reklamową do innych opłat lokalnych, w zakresie których również trudno dopatrywać się istnienia ekwiwalentu ponoszonej opłaty. Tak jest w opłacie miejscowej, uzdrowiskowej czy od posiadania psów uregulowanych w tej samej ustawie co opłata reklamowa.

W literaturze wskazuje się, że „wprawdzie gminie przysługuje prawo do poboru opłaty reklamowej jedynie po przyjęciu aktów prawa miejscowego regulujących zasady i warunki sytuowania obiektów małej architektury, tablic reklamowych i urządzeń reklamowych oraz ogrodzeń (z tylko tych obszarów, na których te zasady obowiązują), jednak nie sposób uznać, że przyjęcie wskazanych aktów prawa miejscowego stanowi świadczenie związane z uiszczanymi opłatami. Podmiot obowiązany do ponoszenia opłaty reklamowej może wprawdzie korzystać z faktu przyjęcia miejscowej legislacji nakierowanej na poprawę ładu przestrzennego, a korzyść przez niego odnoszona może także bezpośrednio odnosić się do użytkowanego przez niego urządzenia reklamowego lub tablicy reklamowej (np. poprzez wzrost skuteczności reklamy wynikający ze zmniejszenia ilości innych reklam i poprawy estetyki otoczenia), jednak nie można traktować przyjęcia aktu prawa miejscowego jako świadczenia będącego ekwiwalentem ponoszonej opłaty"30.

W doktrynie wskazuje się na trzy różne kategorie opłat publicznych, tj. opłaty administracyjne (po uiszczeniu tej opłaty podmiot otrzymuje świadczenie zwrotne w postaci czynności urzędowej) ${ }^{31}$, opłaty pobierane za usługi podmiotów publicznych ${ }^{32}$ oraz opłaty wiążące się z prawną ochroną wartości środowiska ${ }^{33}$. Odnosząc te powyższe kategorie

${ }^{29}$ D. Antonów, Charakter prawny..., op. cit., s. 116.

${ }^{30} \mathrm{~J}$. Wantoch-Rekowski, O opłacie reklamowej..., op. cit., s. 292-293.

${ }^{31}$ Więcej na temat opłat administracyjnych w: D. Antonów, Pojęcie opłaty administracyjnej w polskim języku prawnym i prawniczym, [w:] Z. Ofiarski (red.), XXV lat przeobrażeń w prawie finansowym i prawie podatkowym: ocena dokonań $i$ wnioski na przyszłość, Szczecin 2014, s. 367 i n.

${ }^{32}$ Szerzej na ten temat: D. Antonów, Świadczenia pieniężne związane z działalnością administracji publicznej [w:] E. Ura, E. Feret, S. Pieprzny (red.), Jednostka wobec działań administracji publicznej, Rzeszów 2016, s. 685 i n.

${ }^{33} \mathrm{Na}$ temat tej kategorii opłat publicznych zob. J. Gliniecka, Opłaty publiczne w Polsce. Analiza prawna i funkcjonalna, Bydgoszcz - Gdańsk 2007, s. 70. 
opłat do analizowanej opłaty reklamowej można dostrzec kilka podobieństw do opłat związanych z korzystaniem ze środowiska. Sam ustawodawca wskazuje, że opłata reklamowa nie ma charakteru fiskalnego, a stanowi instrument ochrony krajobrazu. Powyższe stwierdzenie może wskazywać, że opłacie reklamowej bliżej jest do kategorii opłat aniżeli do kategorii innych świadczeń publicznoprawnych. Jednakże analiza konstrukcji prawnej zaburza tę koncepcję całkowicie. Brak cechy odpłatności, a także to, że opłata reklamowa pobierana jest od właścicieli nieruchomości, na której postawione są tablice lub urządzenia reklamowe, a nie od właścicieli tych tablic lub urządzeń sugeruje, iż opłata reklamowa jest kolejną formą publicznoprawnego obciążenia nieruchomości ${ }^{34}$.

W związku z powyższym konstrukcja podmiotu i przedmiotu tej opłaty zbliża ją wyraźnie do podatku od nieruchomości, stanowiąc tym samym kategorię świadczenia pobieranego z tytułu szczególnej formy korzystania z nieruchomości. Za tym poglądem przemawia także fakt, że ustawodawca w przepisach prawa podatkowego wprowadza możliwość zaliczenia podatku od nieruchomości na poczet opłaty reklamowej. Powyższe argumenty mogą kwalifikować opłatę reklamowa do kategorii podatków. Jednakże najważniejszą funkcją podatków jest funkcja fiskalna, która także świadczy o kwalifikacji do tej kategorii danin publicznych. W przypadku opłaty reklamowej roli pierwszorzędnej nie odgrywają funkcje fiskalne, a funkcje pozafiskalne (społeczne), co niewątpliwie nie pozwala nam zakwalifikować tego świadczenia do podatków ${ }^{35}$.

\section{Problemy praktyczne i uwagi de lege ferenda}

Pierwszym problemem, który nasuwa się po analizie przepisów regulujących konstrukcję prawną opłaty reklamowej, jest kwestia mylącej nazwy opłaty w zakresie postrzegania podmiotu zobowiązanego do regulowania tego świadczenia na rzecz związku publicznoprawnego

\footnotetext{
${ }^{34}$ D. Antonów, Charakter prawny opłaty reklamowej..., op. cit., s. 116-117.

${ }^{35}$ Ibidem.
} 
Sylwia Gontowska, Robert Kwaśniewski - Opłata reklamowa...

(w tym przypadku gminy). Mianowicie z punktu widzenia podmiotu, na którym ciąży obowiązek z tytułu tej opłaty, jej nazwa może wprowadzać w błąd, ponieważ podmiotem zobowiązanym do uiszczania opłaty reklamowej nie jest właściciel tablicy reklamowej lub urządzenia reklamowego, na których faktycznie organizuje on ekspozycję reklamy, a właściciel nieruchomości lub obiektu budowlanego (lub podmiot dysponujący innym tytułem do nieruchomości wskazanym w ustawie), na których umieszczone są tablice lub urządzenia reklamowe (nawet wtedy, gdy na takich urządzeniach nie widnieje reklama). Biorąc pod uwagę wykładnię językową, podmiotem zobowiązanym do zapłaty opłaty reklamowej powinny być podmioty czerpiące korzyści majątkowe $\mathrm{z}$ ekspozycji swojej reklamy na tablicach lub urządzeniach reklamowych.

Wątpliwości może także rodzić określenie głównego celu opłaty reklamowej. Jak już wcześniej wspomniano opłata reklamowa nie stanowi w zamierzeniu ustawodawcy źródła dodatkowego dochodu publicznego, lecz jest jednym z instrumentów zmierzających do uporządkowania przestrzeni publicznej i ochrony krajobrazu. Funkcja fiskalna w tym przypadku nie ma większego znaczenia, gdyż pierwszorzędne znaczenie będą miały funkcje pozafiskalne. Jak wskazują teoretycy prawa podatkowego opłata reklamowa posiada istotny walor regulacyjny, który dominuje nad funkcją fiskalną ${ }^{36}$. Cel regulacyjny wyraża się w tym, że ciężar publiczny, który miałby być poniesiony w związku z opłatą reklamową spowoduje zmniejszenie liczby reklam i urządzeń reklamowych w przestrzeni publicznej, co w konsekwencji doprowadzi do zapobieżenia degradacji ładu krajobrazowego ${ }^{37}$.

Kolejnym dość istotnym problemem, na który zwracano już uwagę w opracowaniu, jest problem wyłączenia z opłaty reklamowej tablic lub urządzeń reklamowych niewidocznych z przestrzeni dostępnej publicznie. Ustawodawca w uzasadnieniu do ustawy wskazywał, że opłata reklamowa nawiązuje do kwestii kształtowania krajobrazu, a zatem zasadnym jest uwolnienie od tego obowiązku właścicieli nieruchomości, na

${ }^{36}$ Zob. D. Antonów, Charakter prawny..., op. cit., s. 106-118; A. Fogel, G. Goleń (red.), Komentarz do ustawy z dnia 24 kwietnia 2015 r. o zmianie niektórych ustaw $w$ zwiqzku ze wzmocnieniem narzędzi ochrony krajobrazu (stan prawny: 1 grudnia 2015 r.), LEX el.

${ }^{37}$ D. Antonów, Charakter prawny..., op. cit., s. 107-108. 
których są zlokalizowane obiekty reklamowe niewidoczne z przestrzeni publicznej. Kwestią sporną jednak jest ustalenie, co oznacza pojęcie „widoczność z przestrzeni dostępnej publicznie”, tym bardziej, że trudno wyobrazić sobie wiele przykładów takich nieruchomości, skoro idea lokowania urządzeń reklamowych związana jest właśnie z widocznością i to jak największą. W przepisach prawa podatkowego oraz przepisach regulujących planowanie przestrzenne próżno szukać definicji legalnej tego jakże kluczowego pojęcia, które wpływa na kwestię zwolnienia danego podmiotu od obowiązku regulowania opłaty reklamowej. Mimo tego, że ustawodawca w przepisach ustawy o planowaniu i zagospodarowaniu przestrzennym posługuje się pojęciem „obszaru przestrzeni publicznej”, to nie należy go utożsamiać z pojęciem „przestrzeni publicznej" użytej w przepisach ustawy o podatkach i opłatach lokalnych, gdyż nie zdecydował się on na odesłanie do przepisów innej ustawy w związku z tym pojęciem. Dobrze by było, aby ustawodawca „przy okazji" kolejnych działań legislacyjnych i nowelizacyjnych wprowadził do przepisów ustawy o podatkach i opłatach lokalnych definicję legalną pojęcia „przestrzeń publiczna”. Zawarcie takiej definicji w przepisach prawa pozwalałoby uniknąć wielu obecnie występujących wątpliwości w procesie stosowania prawa przez jednostki samorządu terytorialnego.

Opłata reklamowa jest świadczeniem pieniężnym związanym z legalnym (zgodnym z prawem) umieszczaniem urządzeń reklamowych bądź tablic reklamowych z informacjami reklamowymi. Kwestią niejednoznaczną pozostaje jednak to, czy niezgodne z prawem lokowanie tablic bądź urządzeń reklamowych wyłącza obowiązek z tytułu opłaty reklamowej. W takim przypadku przewidziana została w art. 37d u.p.z.p kara pieniężna za niezgodne z prawem umieszczanie reklam ${ }^{38}$.

W zakresie uwag de lege ferenda zasadny wydaje się postulat, aby ustawodawca zlikwidował wcześniej omawiany podział opłaty reklamowej na części: stałą i zmienną. Obecnie obie części zostały uzależnione od kryterium czasu (liczonego w dniach), w którym urządzenie reklamowe bądź tablica reklamowa pozostają na nieruchomościach.

${ }^{38}$ Więcej na ten temat: T. Brzezicki, Kara za niezgodne $\mathrm{z}$ prawem umieszczenie reklam, „Przegląd Podatkowy” 2016, nr 8, s. 35-40. 
Sylwia Gontowska, Robert Kwaśniewski - Opłata reklamowa...

Taki sam efekt można by było uzyskać, różnicując wysokość opłaty (bez podziału na części) ze względu na wielkość urządzenia reklamowego. Przyniosłoby to taki sam efekt fiskalny, a jednocześnie uprościłoby zasady obliczenia wysokości opłaty reklamowej.

Kolejnym postulatem wyprowadzonym w toku analizy przepisów dotyczących stawki opłaty reklamowej, jest konieczność zmiany sposobu ustalania stawki tej opłaty. Powinna być ona dokonywana na podstawie okresów rocznych, a nie dziennych, jak to ma miejsce obecnie. Taki mechanizm spowodowałby ułatwienie procesu poboru opłaty i zmniejszenie kosztów administracyjnych, które powstają w związku z czynnościami wykonywanymi przez inkasentów. W przypadku opłaty reklamowej mamy do czynienia z zachowaniem biernym podatnika, więc w praktyce korzystniejsze byłoby pobieranie tej opłaty rocznie, tak jak w przypadku opłaty od posiadania psów.

Należy zwrócić także uwagę, że ustawodawca nie zawarł w ustawie o podatkach i opłatach lokalnych przepisów dotyczących momentu powstania i wygaśnięcia obowiązku z tytułu opłaty reklamowej. W doktrynie jednak wskazuje się, że skoro wysokość tej opłaty jest uzależniona od liczby dni, to można przyjąć, że obowiązek ten powstaje od dnia, w którym urządzenie reklamowe bądź tablica reklamowa jest eksponowana na nieruchomości (obiekcie budowalnym) ${ }^{39}$. Ustawodawca powinien w przepisach jasno wskazać jaki jest moment powstania i wygaśnięcia obowiązku z tytułu opłaty reklamowej, co ułatwiłoby podmiotom zobowiązanym interpretację przepisów prawa podatkowego.

\section{Podsumowanie}

Opłata reklamowa, wprowadzona przez ustawodawcę do polskich przepisów prawa podatkowego ponad dwa lata temu, nie stanowi w jego zamierzeniu źródła dodatkowego dochodu publicznego dla gmin, lecz jest jednym z instrumentów zmierzających do uporządkowania

${ }^{39}$ Szerzej na ten temat: M. Łyczek, Opłata reklamowa - nowa opłata lokalna jako instrument ochrony krajobrazu, „Przegląd Podatków Lokalnych i Finansów Samorządowych" 2015, nr 6, s. 18-24. 
przestrzeni publicznej i ochrony krajobrazu. Spełniając funkcje pozafiskalne nastawiona jest na ochronę krajobrazu przed naruszeniem ładu krajobrazowego spowodowanym lawiną reklam w przestrzeni publicznej. Analiza teoretyczna opłaty reklamowej, która została przeprowadzona w artykule, nie tylko ujawniła niedoskonałości czy luki konstrukcyjne tej daniny publicznej, ale przede wszystkim dowodzi jej niejednoznacznego charakteru prawnego. W żaden sposób opłaty reklamowej nie da się jednoznacznie i bez zastrzeżeń zakwalifikować do określonej kategorii świadczeń publicznoprawnych - czy to do podatków czy to do opłat. Opłatę reklamową można zakwalifikować jako daninę publiczną o niejednolitym charakterze, która stanowi szczególną kategorię obciążeń publicznoprawnych nieruchomości. Opłata reklamowa jest jednym z instrumentów ochrony krajobrazu, a nie kolejnym źródłem dochodu dla gmin, które zdecydują się na jej wprowadzenie.

Istnienie opłaty reklamowej w polskim porządku prawnym budzi uzasadnione wątpliwości prawne zarówno z punktu widzenia jej funkcji fiskalnych, jak i pozafiskalnych. Dogłębna analiza przepisów prawa podatkowego w zakresie opłaty reklamowej pozwoliła wyodrębnić kilka problemów praktycznych, z którymi mogą się spotkać samorządy gmin oraz podmioty zobowiązane do uiszczania tej opłaty. Wyodrębnione problemy praktyczne stały się przyczynkiem do sformułowania uwag de lege ferenda, które ustawodawca mógłby wprowadzić na etapie kolejnych nowelizacji ustawy, co niewątpliwie przyczyniłoby się do zniwelowania tych wątpliwości i wprowadzeniu pełnej spójności przepisów.

\section{Bibliografia:}

Antonów D., Charakter prawny opłaty reklamowej, [w:] „Finanse Komunalne” 2017, nr 1-2.

Antonów D., Świadczenia pieniężne związane z działalnością administracji publicznej, [w:] E. Ura, E. Feret, S. Pieprzny (red.), Jednostka wobec działań administracji publicznej, Wyd. RS Druk, Rzeszów 2016.

Antonów D., Pojęcie opłaty administracyjnej w polskim języku prawnym i prawniczym, [w:] Z. Ofiarski (red.), XXV lat przeobrażeń w prawie finansowym 
Sylwia Gontowska, Robert Kwaśniewski - Opłata reklamowa...

i prawie podatkowym: ocena dokonań i wnioski na przyszłość, Wyd. Uniwersytetu Szczecińskiego, Szczecin 2014.

Brzezicki T., Kara za niezgodne z prawem umieszczenie reklam, „Przegląd Podatkowy" 2016, nr 8.

Brzezicki T., Komentarz do art. 17a ustawy o podatkach i opłatach lokalnych,

[w:] W. Morawski (red.), Ustawa o podatkach i opłatach lokalnych. Komentarz, Wyd. ODDK, Gdańsk 2016.

Brzeziński B., Wprowadzenie do prawa podatkowego, Wyd. TNOiK, Toruń 2008. Brzeziński B., Olesińska A. (red.), Prawo finansów publicznych, Wyd. TNOiK, Toruń 2017.

Czarnecki S. Opłata reklamowa - wątpliwe źródło dochodów gmin?, „Przegląd Podatków Lokalnych i Finansów Samorządowych" 2016, nr 3.

Fogel A., Goleń G. (red.), Komentarz do ustawy z dnia 24 kwietnia 2015r. o zmianie niektórych ustaw $w$ zwiq̨zku ze wzmocnieniem narzędzi ochrony krajobrazu (stan prawny: 1 grudnia 2015 r.), LEX el.

Fogel A., Goleń G., Staniewska A. (red.), Ustawa krajobrazowa. Komentarz do przepisów wprowadzonych $w$ zwiq̨zku ze wzmocnieniem narzędzi ochrony krajobrazu, Wyd. Wolters Kluwer, Warszawa 2016.

Gliniecka J., Opłaty publiczne w Polsce. Analiza prawna i funkcjonalna, Wyd. Oficyna wydawnicza Branta, Bydgoszcz - Gdańsk 2007.

Hadel M., Opłata reklamowa jako instrument kształtowania gminnej polityki przestrzennej, „Finanse Komunalne” 2016, nr 7-8.

Łyczek M., Opłata reklamowa - nowa opłata lokalna jako instrument ochrony krajobrazu, „Przegląd Podatków Lokalnych i Finansów Samorządowych” 2015, nr 6, s. 18-24.

Ofiarski Z., Ogólne prawo podatkowe. Zagadnienia materialnoprawne i proceduralne, Wyd.LexisNexis, Warszawa 2013.

Pahl B., Podatki i opłaty lokalne. Teoria i praktyka, Wyd. Wolters Kluwer, Warszawa 2017.

Stelmaszczyk K. Komentarz do art. 17a ustawy o podatkach i opłatach lokalnych, [w:] Borszowski P., Stelmaszczyk K., Podatki i opłaty lokalne, podatek rolny, podatek leśny. Komentarz, Wyd. Wolters Kluwer, Warszawa 2016.

Wantoch-Rekowski J., O opłacie reklamowej, [w:] Miemiec W. (red.), Księga Jubileuszowa Profesor Krystyny Sawickiej. Gromadzenie i wydatkowanie środków publicznych. Zagadnienia finansowoprawne, Wyd. Oficyna Wydawnicza „Unimex”, Wrocław 2017. 